\title{
PENILAIAN TERHADAP SIFAT-SIFAT FISIKA DAN KIMIA TANAH SERTA KUALITASNYA PADA LAHAN SAWAH MARJINAL
}

\section{Assessment of Physical and Chemical Properties and their Quality of Soil of Marginal Sawah Land}

\author{
Latief Mahir Rachman $^{1 *}$, Fahrizal Hazra ${ }^{1}$, Rahma Anisa ${ }^{2}$ \\ ${ }^{1}$ Departemen Ilmu Tanah dan Sumberdaya Lahan, Fakultas Pertanian, Institut Pertanian Bogor \\ ${ }^{2}$ Departemen Statistika, Fakultas Matematika dan Ilmu Pengetahuan Alam, Institut Pertanian Bogor \\ *Penulis korespondensi: latiefra@apps.ipb.ac.id
}

\begin{abstract}
Various efforts have been carried out by the Indonesian Government to increase rice production, especially the construction of new paddy fields and paddy intensification through increasing intensity or planting frequency in a year. Overcoming the problems of chemical and physical soil properties that have caused low soil productivity is an effort that can be made to increase rice production. This study was aimed to assess the quality of soil physical and chemical properties of the paddy fields to find out the cause of the low productivity of paddy soils. The study was conducted in 24 locations in Banten and West Java Provinces. In general, based on their soil quality indexes, the study found that the soil physical quality of paddy soil is good and better than soil chemical quality. There was no significantly different between soil physical quality of paddy soil in Banten and West Java Provinces. However, the soil chemical quality of paddy soils in West Java Province is significantly better than in Banten Province. There were no limiting factors for soil physical properties, while in some locations, some limiting factors of soil chemicals properties were found. Dominant limiting factors for plant growth were the low available $\mathrm{P}$, organic matter and total organic $\mathrm{N}$ contents, low $\mathrm{pH}$, and low exchangeable $\mathrm{K}$, and high level of Fe.
\end{abstract}

Keywords: marginal land, rice field land, soil chemical quality, soil physical quality, soil quality assessment

\section{Pendahuluan}

Tanaman padi masih merupakan tanaman pangan utama dan salah satu tanaman budidaya terpenting di Indonesia. Tanaman padi pada umumnya dibudidayakan pada lahan persawahan, terutama yang memiliki berbagai level jaringan irigasi (Umar, 2018). Semakin menurunnya luas tanah sawah akibat alih fungsi lahan sawah untuk lahan non pertanian, terutama perluasan wilayah pemukiman, industri dan infrastruktur serta lambatnya pembangunan dan pencetakan sawah baru semakin mengancam pencapaian produksi padi untuk pemenuhan kebutuhan beras. Konversi lahan sawah di Provinsi Jawa Barat dan Provinsi Banten termasuk yang terpesat. Selama 12 tahun
(2000-2013), konversi lahan sawah di Jawa Barat mencapai sekitar 48.000 ha atau 4.000 ha per tahun (Mulyani et al., 2018). Wilayah Pantai Utara di Provinsi Jawa Barat dan Provinsi Banten merupakan wilayah yang paling luas dan intensif mengalami konversi lahan persawahan (Las dan Mulyani 2009).

Intensifikasi tanah sawah untuk mempertahankan dan meningkatkan produktivitas tanah sawah merupakan salah satu strategi yang tepat dalam upaya pencapaian program swasembada pangan dan ketahanan pangan, khususnya beras. Sebagian besar lahan persawahan di Indonesia tergolong ke dalam lahan suboptimal atau lahan marjinal, yang dicirikan dengan adanya faktor pembatas yang 


\section{Jurnal Tanah dan Sumberdaya Lahan Vol 7 No 2 : 225-236, 2020 e-ISSN:2549-9793, doi: 10.21776/ub.jts1.2020.007.2.6}

dimiliki tanah sehingga menghasilkan produktivitas yang rendah. Untuk melakukan intensifikasi pada lahan persawahan yang tergolong lahan marjinal, perlu diidentifikasi faktor-faktor apa yang sebenarnya menjadi penyebab rendahnya produktivitas tanah sawah pada lahan suboptimal. Aprisal et al. (2016) menyatakan bahwa permasalahan utama pada lahan suboptimal ini adalah sifat fisika, kimia dan biologi tanah yang buruk, seperti kepadatan tanah yang tinggi dan kapasitas air tersedia untuk tanaman yang sangat rendah. Upaya peningkatan produktivitas tanaman pangan di Indonesia akan semakin bergantung pada pemenuhan kebutuhan unsur hara dalam tanah, terutama nitrogen $(\mathrm{N})$, fosfor $(\mathrm{P})$, dan kalium $(\mathrm{K})$.

Semakin meluasnya lahan suboptimal disebabkan oleh manajemen tanah yang tidak mengikuti pedoman atau kaedah konservasi tanah dan air serta konversi lahan hutan dan tataguna lahan lainnya yang menyebabkan berkurangnya penutupan lahan oleh vegetasi yang pada akhirnya menyebabkan terjadinya degradasi tanah, terutama di daerah tropis dan subtropis (Lal, 2001; Holthusen et al., 2018). Tanah merupakan penyedia seluruh kebutuhan untuk menunjang pertumbuhan dan produksi tanaman. Tanah yang subur bagi pengembangan pertanian adalah tanah yang memiliki kapasitas untuk memenuhi seluruh kebutuhan tanaman, yaitu mampu menyediakan seluruh unsur hara yang dibutuhkan tanaman dalam jumlah yang cukup dan seimbang, memenuhi kebutuhan airnya, memasok gas-gas yang dibutuhkan serta memiliki fisik tanah yang cukup gembur untuk ditembus sistem perakaran tanaman namun tetap dapat menunjang tanaman berdiri kokoh (Rachman, 2019). Tanah juga berfungsi untuk menyediakan layanan ekosistem seperti produksi tanaman, retensi air dan sekuestrasi karbon organik tanah (Regelink et al., 2015). Tanah merupakan bahan yang permeabel berupa ruang-ruang yang saling terhubung dan sinambung yang memungkinkan terjadinya aliran cairan dan/atau air ketika terjadi perbedaan energi potensial (Elhakim, 2016).

Sifat-sifat fisik tanah memberikan kontribusi terhadap pertumbuhan dan produksi tanaman yang secara garis besar dapat dibagi ke dalam 3 aspek, yaitu: 1) sebagai media fisik terdapat nya atau tempat keberadaan unsur hara, air dan udara atau gas-gas yang dibutuhkan tanaman serta tempat berjangkarnya perakaran tanaman, 2) pengendali penyediaan air tersedia bagi tanaman, 3) pengendali proses pemasokan gas-gas yang dibutuhkan tanaman (Rachman, 2019). Menurut $\mathrm{Fu}$ et al. (2019), pemadatan tanah dapat mengakibatkan perubahan porositas tanah dan distribusi ukuran pori tanah. Bobot atau kerapatan isi adalah sifat fisik tanah yang penting dan menentukan aerasi tanah dan karakteristik air tanah (Martín et al., 2017; Lu et al., 2019). Lawes et al. (2009) dan Hosseini et al. (2016) menyatakan bahwa manajemen yang memadai terhadap kandungan air tanah sangat krusial untuk pertumbuhan dan produksi tanaman Air tersedia tanah (soil available water) adalah jumlah air yang dapat dilepas oleh tanah diantara kapasitas lapang dan titik layu permanen (Arya et al., 2008).

Sifat-sifat kimia tanah meliputi kandungan unsur-unsur kimia yang terdapat di dalam tanah serta ketersediaannya bagi pertumbuhan dan produksi tanaman. Unsur hara essensial tanah yang dibutuhkan untuk menunjang pertumbuhan dan produksi tanaman dapat digolongkan ke dalam unsur hara makro, yang dibutuhkan tanaman dalam jumlah banyak (terutama C, H, O, N, P, K, Ca, Mg, S) serta unsur hara mikro yang dibutuhkan tanaman dalam jumlah sedikit (Fe, Zn, Mn, Cu, Cl, Co, Mo, B). Oleh karena itu, meskipun karbon organik merupakan komponen biologi tanah, namun masih sering dikelompokkan ke dalam sifat kimia tanah. Ketersediaan unsur-unsur hara tersebut bagi tanaman sangat ditentukan oleh kapasitas tukar kation, kejenuhan basa dan reaksi tanah atau $\mathrm{pH}$ tanah.

Kualitas tanah semula hanya dikaitkan dengan produktivitas tanah, namun telah berkembang dan diperluas untuk memasukkan fungsi kapasitas tanah dalam batas-batas ekosistem untuk mempertahankan produktivitas biologis, menjaga kualitas lingkungan dan mempromosikan kesehatan tumbuhan dan hewan (Hornick 1992; Doran dan Parkin 1994). Kualitas tanah adalah konsep multidimensi berdasarkan penggunaan indikator. Indikator penilaian terintegrasi memberikan lebih banyak informasi daripada data individu dan kumpulan parameter pilihan; menyelesaikan aspek operasional dan ekonomi dari evaluasi dan pemantauan (Rojas et al., 2016). 
Kualitas tanah meliputi sifat fisik, kimia dan biologis tanah semuanya memberikan informasi tentang berbagai aspek tanah sebagai sebuah sistem (Zuber et al., 2017).

Kualitas fisik tanah yang baik, ditunjukkan oleh skor indeks kualitas fisik tanahnya yang tinggi, menjamin pasokan air dan udara yang dibutuhkan oleh tanaman serta kemudahan tanah untuk ditembus perakaran tanaman. Kualitas kimia tanah yang baik, yang ditunjukkan oleh skor indeks kualitas kimia tanahnya yang tinggi mengindikasikan memiliki kandungan unsur-unsur hara essensial tanah dalam jumlah yang cukup serta mendukung penyediaan dan pemenuhan unsur-unsur hara yang dibutuhkan oleh tanaman dalam jumlah yang cukup dan seimbang.

Meningkatkan dan mempertahankan kualitas tanah sangat penting untuk memastikan produktivitas pertanian, ketersediaan air dan kualitas lingkungan secara keseluruhan (de Paul Obade dan Lal 2014). Peningkatan kualitas tanah dapat membangun ketahanan dalam sistem produksi berbasis lahan untuk memungkinkan kapasitas buffer dan adaptasi yang dapat mengurangi dampak merugikan dari peningkatan variabilitas iklim dan frekuensi kejadian cuaca ekstrim seperti kekeringan atau banjir (de Paul Obade dan Lal, 2014; Kiani et al., 2017).

Tujuan penelitian ini adalah untuk melakukan penilaian terhadap sifat-sifat kimia tanah dan fisika tanah serta kualitas kimia tanah dan fisika tanah pada lahan sawah agar mengetahui faktor apa sebenarnya menjadi penyebab dari masih rendahnya produktivitas tanah sawah.

\section{Bahan dan Metode}

\section{Lokasi dan waktu penelitian}

Penelitian dilaksanakan dari bulan Mei sampai Desember 2018, merupakan bagian dari rangkaian penelitian Penelitian Terapan Unggulan Perguruan Tinggi tahun pertama. Penelitian terdiri atas survei lapang disertai dengan pengambilan sampel tanah dengan menggunakan metode komposit pada lapisan atas tanah $(0-20 \mathrm{~cm})$ serta selanjutkan dikirim ke laboratorium. Lokasi survei lapangan dan pengambilan sampel tanah pada lahan sentra komoditas padi di setiap kabupaten terpilih, yaitu Kabupaten Cianjur, Karawang dan Subang untuk Provinsi Jawa Barat dan Kabupaten Serang, Lebak dan Pandeglang untuk Provinsi Banten. Lokasi penelitian yang dipilih tersebut merupakan sentra penghasil padi andalan di Provinsi Jawa Barat dan Provinsi Banten.

\section{Teknik penilaian sifat-sifat dan kualitas fisik dan kimia tanah}

Kualitas fisik dan kimia tanah tidak dapat diukur secara langsung. Informasi kualitas fisik dan kimia tanah biasanya disimpulkan dari atribut fisik dan kimia tanah yang diamati dan dianalisa atau dimodelkan (Lal, 2001). Tantangan aspek metodologis adalah untuk mengidentifikasi seperangkat sifat sifat fisik dan kimia tertentu yang dapat dijadikan sebagai standar yang relevan sebagai indikator kualitas fisik dan kimia tanah yang bermakna dan yang sensitif terhadap perubahan yang dipicu oleh manajemen. Acuan pemilihan parameter atau sifat-sifat fisik dan kimia untuk dijadikan parameter utama (key parameter) dalam penilaian kualitas fisik tanah disajikan pada Tabel 1 dan Tabel 2. Penilaian sifat-sifat dan kualitas fisik dan kimia tanah menggunakan sistem indeks pada dasarnya adalah menentukan indeks rata-rata tertimbang yang berasal dari skor dari masing-masing parameter kunci (key parameters) terpilih dikalikan dengan bobotnya (weighting coefficient).

\section{Tahapan penilaian skor akhir kualitas fisik} dan kimia tanah

Tahapan utama dalam analisa dan penilaian sifat-sifat fisik dan kimia tanah serta pengkatagorisasian adalah sebagai berikut:

1. Memilih data set minimum dari parameter kunci sifat-sifat fisik dan kimia tanah. Data set minimum parameter kunci beserta simbol dan koefisien pembobot (weighting coefficient) sesuai dengan peran/ fungsinya (lihat Tabel 1).

2. Menetapkan cara pemberian skor setiap parameter, skor 0 (paling buruk) sampai 5 (paling baik) (lihat Tabel 2)

3. Memberikan skor 1 sampai 5 untuk masingmasing parameter, sesuai dengan kondisi dan kinerjanya seperti yang disajikan pada Tabel 2.

4. Menghitung masing-masing skor akhir kualitas fisik dan kimia tanah dengan cara 
menjumlahkan skor yang diperoleh oleh setiap parameter.

$$
\begin{gathered}
\text { TSPi }=\text { Pi . SPi } \\
\text { TSSQI }=\sum_{1}^{n} \mathrm{Pi} . \text { SoPi }
\end{gathered}
$$

dimana: TSPi $=$ skor total parameter sifat fisik atau tanah $\mathrm{I}, \mathrm{Pi}=$ proporsi (koefisien bobot) dari parameter sifat fisik atau kimia tanah I, SoPi $=$ skor parameter tanah $\mathrm{I}, \mathrm{n}=$ jumlah parameter tanah, dan TSSQI = total skor Indeks Kualitas Fisik atau Kimia Tanah $=$ Indeks Kualitas Fisik atau Kimia Tanah

5. Skoring akhir kualitas fisik atau kimia dihitung dari total skor total setiap parameter tanah. Total skor masing-masing parameter ditemukan dari perkalian proporsi (koefisien pembobotan) dan skor masing-masing parameter (skala 1 sampai 5). Dengan demikian, total skor akhir kualitas fisik atau kimia tanah, secara teoritis, bervariasi dari 0 hingga 5 , misalnya $3.06,4.89,2.45$, dan lain lain skor di bawah 5.0.

6. Mengkatagorisasikan skor akhir kulitas fisik atau kimia tanah tersebut ke dalam 7 katagori (lihat Tabel 3).

7. Menguji apakah rata-rata skor indeks kualitas fisik dan kimia tanah pada Provinsi Banten sama atau berbeda nyata dengan yang di Provinsi Jawa Barat dengan metode uji T-test.

Tabel 1. Parameter kunci untuk penilaian sifat-sifat dan kualitas fisik dan kimia tanah pada tanah

\begin{tabular}{|c|c|c|c|c|}
\hline No & Simbol & Parameter Kunci & Bobot $^{* * *}$ & Metode \\
\hline \multicolumn{5}{|c|}{ Sifat Fisik } \\
\hline 1 & $\mathrm{~S}$ & Kedalaman Efektif* & 0,40 & Pengamatan Lapangan \\
\hline 2 & $\mathrm{~T}$ & Tekstur Tanah & 0,30 & Pipet \\
\hline 3 & $\mathrm{D}$ & Drainase Tanah & 0,30 & Pengamatan Lapangan \\
\hline & Total & & 1,00 & \\
\hline \multicolumn{5}{|c|}{ Sifat Kimia } \\
\hline 1 & $\mathrm{pH}$ & $\mathrm{pH}$ & 0,12 & $\mathrm{pH}-\mathrm{H}_{2} \mathrm{O}$ \\
\hline 2 & KTK & $\begin{array}{l}\text { KTK (Kapasitas Tukar } \\
\text { Kation) }\end{array}$ & 0,09 & $\begin{array}{c}\text { Ekstraksi } \mathrm{NH}_{4} \mathrm{OAc} 1 \mathrm{M} \mathrm{pH} \\
7,0\end{array}$ \\
\hline 3 & $\mathrm{~KB}$ & Kejenuhan Basa & 0,05 & $\begin{array}{c}\text { Ekstraksi } \mathrm{NH}_{4} \mathrm{OAc} 1 \mathrm{M} \mathrm{pH} \\
7,0\end{array}$ \\
\hline 4 & $\mathrm{~N}_{\mathrm{t}}^{*}$ & Nitrogen organik total & 0,08 & Kjehdahl \\
\hline 5 & $\mathrm{P}_{\mathrm{t}}^{*}$ & Fosfor tersedia & 0,08 & Bray I \\
\hline 6 & $\mathrm{~K}_{\mathrm{d}}{ }^{*}$ & Kalium dapat dipertukarkan & 0,08 & $\begin{array}{c}\text { Ekstraksi } \mathrm{NH}_{4} \mathrm{OAc} 1 \mathrm{M} \mathrm{pH} \\
7,0\end{array}$ \\
\hline 7 & $\mathrm{Cad}^{*}$ & Calcium dapat dipertukarkan & 0,08 & $\begin{array}{c}\text { Ekstraksi } \mathrm{NH}_{4} \mathrm{OAc} 1 \mathrm{M} \mathrm{pH} \\
7,0\end{array}$ \\
\hline 8 & $\mathrm{Mg}_{\mathrm{d}}{ }^{*}$ & Magnesium dapat dipertukarkan & 0,06 & $\begin{array}{c}\text { Ekstraksi } \mathrm{NH}_{4} \mathrm{OAc} 1 \mathrm{M} \mathrm{pH} \\
7,0\end{array}$ \\
\hline 9 & $\mathrm{Al}_{\mathrm{k}}^{* *}$ & Kejenuhan Aluminum & 0,04 & $\begin{array}{c}\text { Ekstraksi } \mathrm{KCl} \text {, penyaringan, } \\
\text { dan titrasi }\end{array}$ \\
\hline 10 & $\mathrm{Fe}^{* *}$ & $\mathrm{Fe}$ (Ferri) & 0,04 & DTPA-AAS \\
\hline 11 & $\mathrm{Cu}^{* *}$ & $\mathrm{Cu}$ (Cuprum) & 0,04 & DTPA-AAS \\
\hline 12 & $\mathrm{Zn}^{* *}$ & Zn (Zink) & 0,04 & DTPA-AAS \\
\hline 13 & $\mathrm{Mn}^{* *}$ & Mn (Mangan) & 0,04 & DTPA-AAS \\
\hline 14 & $\mathrm{Oc}^{*}$ & Karbon-organik & 0,16 & Walkley and Black (1934) \\
\hline & Total & & 1,00 & \\
\hline
\end{tabular}
sawah suboptimal, simbol dan bobot tertimbang serta metode yang digunakan.

Keterangan: * ketebalan lapisan tanah hingga lapisan bajak

LS = Lahan Sawah; ${ }^{*}$ Unsur makro; ${ }^{* *}$ Unsur mikro; ${ }^{* * *}$ Bobot $=$ koefisien penimbang (weighting coefficient) 


\section{Jurnal Tanah dan Sumberdaya Lahan Vol 7 No 2 : 225-236, 2020}

e-ISSN:2549-9793, doi: 10.21776/ub.jts1.2020.007.2.6

Tabel 2. Kriteria untuk pemberian skor terhadap setiap parameter.

\begin{tabular}{|c|c|c|c|c|c|c|c|}
\hline \multirow[t]{3}{*}{ Parameter Kunci } & \multirow[t]{3}{*}{ Satuan } & \multicolumn{6}{|c|}{ Skor Parameter* } \\
\hline & & 0 & 1 & 2 & 3 & 4 & 5 \\
\hline & & Sangat buruk sekali & Sangat buruk & Buruk & Sedang & Baik & Sangat baik \\
\hline \multicolumn{8}{|l|}{ Sifat Fisik } \\
\hline Solum/Kedalaman Efektif (s) & $\mathrm{Cm}$ & $<10$ & $10-15$ & $15-20$ & $20-25$ & $25-35$ & $\geq 35$ \\
\hline Tekstur Tanah (t) & & $\mathrm{P}$ & $\mathrm{P}$ & PL & LP & $\begin{array}{l}\text { Lib,LiP, L, } \\
\text { D,LD,LLiP }\end{array}$ & $\begin{array}{l}\text { Li, LLiD, } \\
\text { LLi, LiD }\end{array}$ \\
\hline Drainase Tanah (d) & & Baik & Agak Baik & Sedang & Agak Buruk & Buruk & Sangat Buruk \\
\hline \multicolumn{8}{|l|}{ Sifat Kimia } \\
\hline $\mathrm{pH}$ & & $<4,0$ & $4,0-4,5$ & $4,5-5,1$ & $5,1-5,8 \& 8,0-8,5$ & $5,8-6,6 \& 7,5-8,0$ & $6,6-7,5$ \\
\hline Kapasitas Tukar Kation (KTK) & me $100 \mathrm{~g}^{-1}$ & $<2$ & $2-5$ & $5-16$ & $17-24$ & $25-40$ & $>40$ \\
\hline Kejenuhan Basa (KB) & $\%$ & $<10$ & $10-20$ & $20-40$ & $40-60$ & $60-80$ & $>80$ \\
\hline Nitrogen organik total $\left(\mathrm{N}_{\mathrm{t}}\right)$ & $\%$ & $<0,05$ & $0,05-0,10$ & $0,11-0,2$ & $0,21-0,50$ & $0,51-0,75$ & $>0,75$ \\
\hline Pospor tersedia $\left(\mathrm{P}_{\mathrm{t}}\right)$ & ppm & $<2$ & $2-4$ & $5-7$ & $8-10$ & $11-15$ & $>15$ \\
\hline Kalium dd $\left(K_{d}\right)$ & me $100 \mathrm{~g}^{-1}$ & $<0,05$ & $0,05-0,1$ & $0,1-0,3$ & $0,4-0,5$ & $0,6-1,0$ & $>1,0$ \\
\hline Kalsium dd $\left(\mathrm{Ca}_{\mathrm{d}}\right)$ & me $100 \mathrm{~g}^{-1}$ & $<1$ & $1-2$ & $2-6$ & $6-11$ & $11-20$ & $>20$ \\
\hline Magnesium dd $\left(\mathrm{Mg}_{\mathrm{d}}\right)$ & me $100 \mathrm{~g}^{-1}$ & $<0,1$ & $0,1-0,3$ & $0,4-1,0$ & $1,1-2,0$ & $2,1-8,0$ & $>8,0$ \\
\hline Kejenuhan Aluminum $\left(\mathrm{Al}_{\mathrm{k}}\right)$ & $\%$ & & $>40$ & $20-40$ & $10-20$ & $5-10$ & $0-5$ \\
\hline Ferri $(\mathrm{Fe})$ & ppm & $<1,0 \&>1500$ & $1,0-2,5 \& 900-1500$ & $\begin{array}{c}2,5-4,0 \& \\
600-900\end{array}$ & $4,0-6,0 \& 300-600$ & $\begin{array}{c}6,0-20,0 \& \\
53-300\end{array}$ & $20,0-53,0$ \\
\hline Cuprum $(\mathrm{Cu})$ & ppm & $<0,1 \&>125$ & $0,1-0,2 \& 60-125$ & $0,2-0,5 \& 20-60$ & $\begin{array}{c}0,5-1,0 \& \\
10-20\end{array}$ & $\begin{array}{c}1,0-1,5 \& \\
2-10\end{array}$ & $1,5-2,0$ \\
\hline Zink (Zn) & $\mathrm{ppm}$ & $<0,10 \&>700$ & $0,1-0,3 \& 40-700$ & $0,3-0,5 \& 20-40$ & $\begin{array}{c}0,5-1,0 \& \\
10-20\end{array}$ & $\begin{array}{c}1,0-1,5 \& \\
2-10\end{array}$ & $1,5-2,0$ \\
\hline Mangan (Mn) & ppm & $<0,05 \&>1500$ & $0,05-1,0 \& 900-1500$ & $1,0-1,5 \& 300-900$ & $1,5-3,0 \& 100-300$ & $3,0-9,0 \& 23-100$ & $9,0-23,0$ \\
\hline Karbon-organik $\left(\mathrm{C}_{\mathrm{o}}\right)$ & $\%$ & $\mathrm{C}_{\mathrm{o}}<0,5$ & $0,5 \leq \mathrm{C}_{0}<1$ & $1 \leq \mathrm{C}_{\mathrm{o}}<2$ & $2 \leq \mathrm{C}_{\mathrm{o}}<3$ & $3 \leq \mathrm{C}_{\mathrm{o}}<5$ & $\mathrm{C}_{\mathrm{o}} \geq 5$ \\
\hline
\end{tabular}

Keterangan: ${ }^{*}$ skoring yang diusulkan oleh penulis.

$\mathrm{Li}=$ liat, $\mathrm{Lib}=$ liat berat, $\mathrm{D}=$ debu, $\mathrm{P}=$ pasir, $\mathrm{L}=$ lempung, $\mathrm{LiD}=$ liat berdebu, $\mathrm{LiP}=$ liat berpasir, $\mathrm{LLi}=$ lempung liat, $\mathrm{LD}=$ lempung berdebu, $\mathrm{LP}=$ lempung berpasir, $\mathrm{LLiD}=$ lempung liat berdebu, LLiP = lempung liat berpasir, PL = pasir lempung 
Jurnal Tanah dan Sumberdaya Lahan Vol 7 No 2 : 225-236, 2020

e-ISSN:2549-9793, doi: 10.21776/ub.jts1.2020.007.2.6

Tabel 3. Katagorisasi skor akhir kualitas fisik dan kimia tanah

\begin{tabular}{cccccccc}
\hline Skor IKT & $0<\mathrm{x} \leq 2,0$ & $2,0<\mathrm{x} \leq 2,5$ & $2,5<\mathrm{x} \leq 3,0$ & $3,0<\mathrm{x} \leq 3,5$ & $3,5<\mathrm{x} \leq 4,0$ & $4,0<\mathrm{x} \leq 4,5$ & $4,5<\mathrm{x} \leq 5,0$ \\
\hline Kategori & Buruk sekali & Buruk & Agak buruk & Sedang & Agak baik & Baik & Baik sekali \\
\hline
\end{tabular}

8. Dibelakang skor akhir kualitas fisik atau kimia, diikuti dengan simbol parameterparameter utama yang menjadi faktor pembatas (parameter dengan nilai sama atau kurang dari 2 (s2.00) dengan katagori rendah).

\section{Hasil dan Pembahasan}

\section{Sifat fisik tanah dan kualitasnya}

Pada Tabel 4 terlihat bahwa skor akhir sifat fisik tanah bervariasi dari terendah 4,30 yang tergolong baik sampai tertinggi 4,70 yang tergolong sangat baik. Seluruh 24 lokasi tanah sawah memiliki kualitas fisik tanah tergolong baik sampai sangat baik. Tidak terlihat perbedaan penyebaran kualitas sifat fisik tanah sawah di Provinsi Banten dan Provinsi Jawa Barat, rata-rata kualitas sifat fisik di kedua provinsi tersebut sama, yaitu 4,45 (katagori baik). Analisis variasi untuk uji perbedaan kualitas fisik tanah Provinsi Banten dengan Provinsi Jawa Barat dengan menggunakan independent t-test dengan galat sebesar 5\% menghasilkan F Tabel sebesar 2,82 dan F Hitung sebesar 0,82, sehingga dapat disimpulkan bahwa kedua data memiliki variasi yang sama. Rumus uji yang digunakan adalah varian yang sama, yakni t-Test: Two-Sample Assuming Equal Variances menghasilkan t tabel sebesar 2,07 dan $t$ stat sebesar 0, dengan demikian hipotesa diterima. Berdasarkan hasil uji tersebut dapat disimpulkan bahwa kualitas sifat fisik pada lahan sawah di Banten sama dengan kualitas sifat fisik pada lahan sawah di Jawa Barat. Tidak ada satu lokasipun yang memiliki faktor pembatas sifat fisik tanah. Dengan demikian dapat dinyatakan bahwa sifat fisik bukan merupakan hambatan atau faktor pembatas bagi tanah-tanah sawah pada lahan sawah sub optimal.

\section{Sifat kimia tanah dan kualitasnya}

Sifat-sifat kimia tanah di 24 lokasi penelitian dan skornya serta skor akhir berikutnya faktor pembatasnya disajikan pada Tabel 5. Seperti terlihat pada Tabel 5, skor akhir sifat kimia di 24 lokasi bervariasi dari terendah 2,46 (katagori buruk) sampai 3.68 (katagori agak baik). Sebagian besar memiliki sifat kimia tanah tergolong sedang (15 lokasi, 62,5\%), 1 lokasi tergolong buruk (4,2\%), 4 lokasi tergolong agak buruk $(16,7 \%)$ dan 4 lokasi tergolong agak baik $(16,7 \%)$. Tidak ada satu lokasi pun yang memiliki skor $\geq 4,5$ dan tergolong baik sekali.

Dari hasil uji variasi untuk menganalisis perbedaan kualitas kimia tanah sawah di Provinsi Banten dan Provinsi Jawa Barat dengan menggunakan independent t-test dengan galat sebesar 5\% diperoleh F Tabel sebesar 2,82 dan F Hitung sebesar 1,94 sehingga dapat diasumsikan kedua data memiliki variansi yang sama. Rumus uji selanjutnya yang digunakan untuk varian yang sama, yakni t-Test: Two-Sample Assuming Equal Variances menghasilkan t tabel sebesar 2,07 dan t stat sebesar -2,12. Dengan demikian hipotesa diterima sehingga dapat disimpulkan bahwa kualitas sifat kimia pada lahan sawah di Banten tidak sama dengan karakteritik kimia pada lahan sawah di Jawa Barat.

Kualitas sifat kimia tanah sawah di Provinsi Banten dalam penelitian ini lebih rendah dibandingkan dengan di Provinsi Jawa Barat. Kualitas sifat kimia tanah sawah di Provinsi Banten bervariasi dari 2,46 (katagori buruk) sampai 3,64 (katagori agak tinggi) dengan ratarata 3,09 (katagori sedang). Sedangkan kualitas sifat kimia tanah sawah di Provinsi Jawa Barat bervariasi dari 3,03 (katagori sedang) sampai 3,68 (katagori agak baik) dengan rata-rata 3,33 (katagori sedang). Hal yang lebih krusial tidak hanya dilihat dari skor akhirnya, tetapi justru berasal dari faktor pembatasnya. Seluruh tanah yang diteliti memiliki satu atau lebih faktor pembatas kimia tanah, bahkan ada yang memiliki sampai 6 (enam) faktor pembatas. Tanah di lokasi 2 merupakan tanah sawah yang nilai skor akhir kualitas tanahnya terendah $(2,46)$ memiliki enam faktor pembatas, yaitu pospor tersedia $\left(\mathrm{P}_{\mathrm{t}}\right)$, sangat rendah, kalium $\left(\mathrm{K}_{\mathrm{d}}\right)$ dapat dipertukarkan dan karbon organik (Co) rendah, 
serta Kapasitas Tukar Kation, Kejenuhan Basa, dan nitrogen organik total $\left(\mathrm{N}_{\mathrm{t}}\right)$ rendah. Dari 24 lokasi, sebanyak 19 lokasi (79,2\%) memiliki dua atau lebih faktor pembatas kimia tanah.

Dalam hal faktor pembatas apa yang paling banyak dijumpai, untuk unsur esensial makro, kandungan Pospor tersedia $\left(\mathrm{P}_{\mathrm{t}}\right)$ yang rendah, dijumpai di 21 lokasi atau 87,5\%. Padahal menurut De Data (1981) dalam Suyono et al. (2010) unsur fosfor (P) merupakan unsur esensial bagi tanaman karena merupakan faktor pembatas yang mempengaruhi pertumbuhan dan produksi tanaman. Pada tanaman padi, unsur $\mathrm{P}$ berperan dalam mendorong pertumbuhan dan perkembangan akar, memicu pembungaan dan pematangan buah terutama pada kondisi iklim rendah, mendorong lebih banyak pembentukan rumpun/anakan yang memungkinkan pemulihan dan adaptasi yang lebih cepat pada saat tanaman padi mengalami cekaman, dan mendukung pembentukan bulir gabah yang lebih baik serta memiliki kandungan gizi yang lebih baik sehubungan dengan kadar P dalam biji. Selanjutnya, unsur makro terbanyak lainnya yang diperlukan oleh tanaman, yaitu kandungan $\mathrm{K}$ dapat dipertukarkan yang rendah juga merupakan faktor pembatas terbanyak berikutnya. Kandungan $\mathrm{K}$ yang rendah terdapat pada 9 lokasi penelitian atau 37,5\%.

Tabel 4. Sifat-sifat fisik tanah dan masing-masing skornya, skor akhirnya serta faktor pembatas.

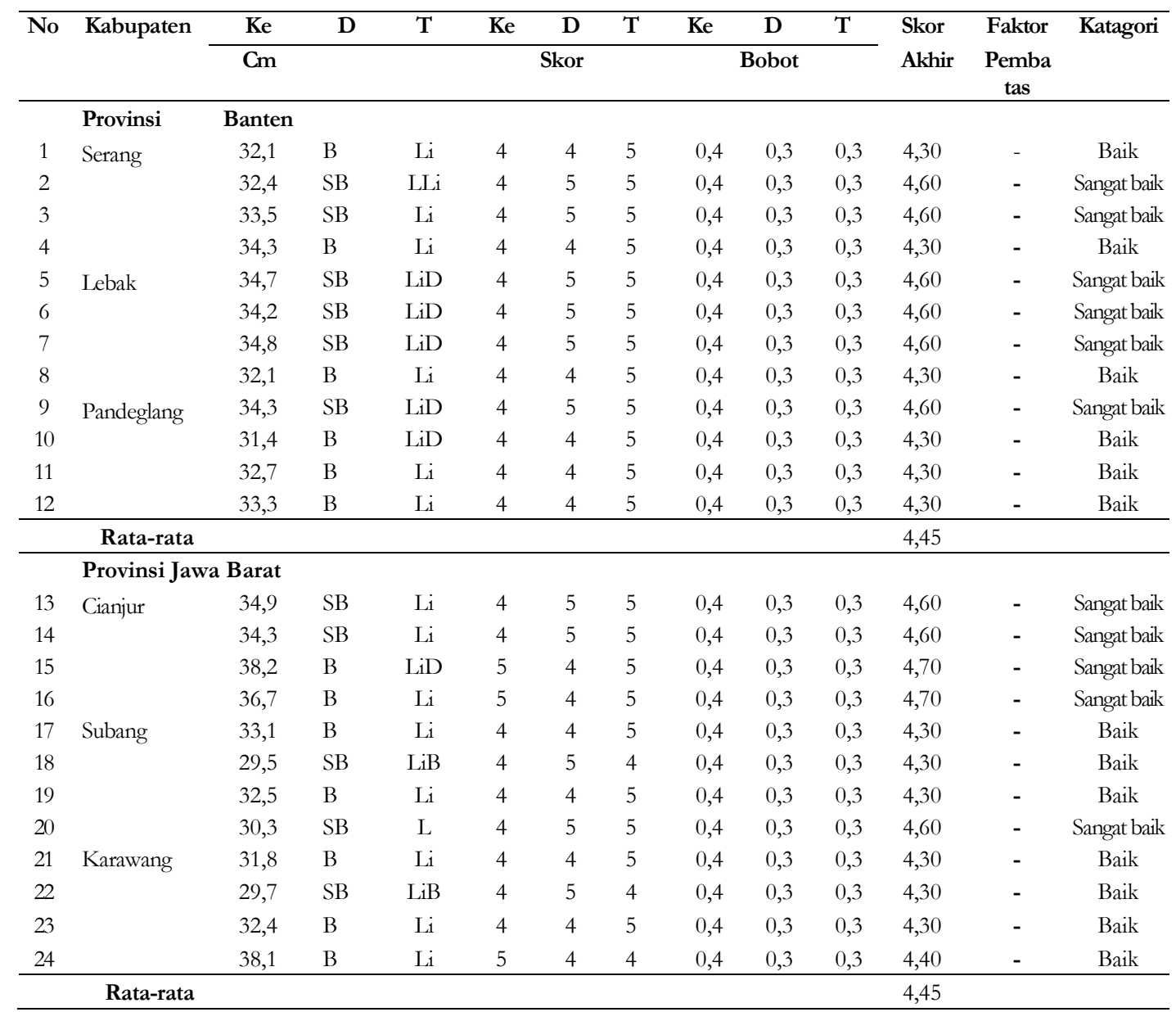

Keterangan: $\mathrm{Ke}=$ kedalaman sampai lapisan bajak; $\mathrm{D}=$ drainase; $\mathrm{T}=$ kelas tekstur; $\mathrm{B}=\mathrm{Buruk} \mathrm{SB}=\mathrm{sangat}$ buruk, $\mathrm{Li}=$ liat $\mathrm{LiB}=$ liat berat $\mathrm{LiD}=$ liat berdebu $\quad \mathrm{LLi}=$ lempung berliat $\quad \mathrm{LD}=$ lempung berdebu, LP $=$ lempung berpasir $\mathrm{LLi}$ $\mathrm{D}=$ lempung liat berdebu $\mathrm{LLiP}=$ lempung liat berpasir $\mathrm{L}=$ lempung. 


\section{Jurnal Tanah dan Sumberdaya Lahan Vol 7 No 2 : 225-236, 2020 e-ISSN:2549-9793, doi: 10.21776/ub.jts1.2020.007.2.6}

Subandi (2013) menyatakan bahwa hasil penelitian di Jawa Barat, menunjukkan bahwa sekitar 225.625 ha dari total 1.213.365 ha atau $18,6 \%$, memiliki kandungan $K$ tanah sawah yang tergolong rendah. Untuk tanaman padi kebutuhan $\mathrm{K}$ melebihi $\mathrm{N}$. K dalam tanaman berfungsi sebagai ion yang sebagian besar berada dalam cairan sel. Peran $\mathrm{K}$ terlibat dalam proses biofisika dan biokimia (Beringer, 1980). Dalam proses biofisika, $K$ berperan penting dalam mengatur tekanan osmosis dan turgor, yang pada gilirannya akan memengaruhi pertumbuhan dan perkembangan sel serta membuka dan menutupnya stomata. Akibat kekurangan $\mathrm{K}$, tanaman akan menurunkan aktivitas fotosintetis karena terganggunya pemasukan $\mathrm{CO}_{2}$ ke daun.. Dalam proses biokimia, peranan $\mathrm{K}$ terkait erat dengan 60 macam reaksi enzimatis, di antaranya enzim untuk metabolisme karbohidrat dan protein. Penyediaan $\mathrm{K}$ yang cukup sangat diperlukan dalam proses pengubahan tenaga surya menjadi tenaga kimia (ATP atau senyawa organik). Pada tanaman yang kekurangan $K$, pengangkutan karbohidrat dari daun ke organ lainnya terhambat sehingga hasil fotosintetis terakumulasi pada daun dan menurunkan kecepatan fotosintetis itu sendiri (Mengel dan Kirkby, 1978). Pada tanaman yang kekurangan $\mathrm{K}$, pembentukan protein akan terganggu sehingga kadar $\mathrm{N}$ protein menurun dan kadar $\mathrm{N}$-bukan protein meningkat.

$\mathrm{N}$ organik total yang rendah dijumpai di 8 lokasi penelitian atau 33,3\% dari total lokasi. $\mathrm{N}$ sangat diperlukan untuk menunjang pertumbuhan dan produksi tanaman, terutama melalui pembentukan dan kualitas daun, kandungan klorofil dan kehijauan daun, laju pertumbuhan tanaman, bobot tanaman kering, bobot gabah per tanaman, dan sebagainya (Faozi dan Wijonarko, 2010).

Kandungan karbon organik rendah dijumpai pada 8 lokasi atau 33,3\% dari total lokasi. Rendahnya kandungan karbon organik menunjukkan bahwa masih rendahnya penggunaan bahan organik pada lahan persawahan. Hesse (1984) menyatakan bahwa penggunaan bahan organik pada lahan pertanian masih terbatas pada lahan kering dengan tanaman bukan padi. Padahal bahan organik sangat berguna untuk memperbaiki kondisi dan kualitas tanah, meningkatkan sifat-sifat fisik, kimia maupun biologi tanah selain peran yang sudah sangat jelas, yaitu meningkatkan kandungan unsur-unsur hara esensial dalam tanah yang diperlukan untuk pertumbahan dan produksi tanaman. Unsur esensial mikro adalah faktor penghambat pada tanah sawah adalah kandungan feri (Fe) dan mangan (Mn) yang terlampau tinggi. kandungan unsur mikro. Fe yang terlalu tinggi (7 lokasi atau 29,2\%), sedangkan Mn terlampau tinggi pada 3 lokasi atau $12,5 \%$ dari seluruh lokasi tanah yang diteliti. Fe dan Mn yang terlampau tinggi dapat menjadi toksik bagi tanaman dan menghambat pertumbuhan tanaman. Dengan demikian, dapat dinyatakan bahwa faktor kimia tanah memberikan kontribusi yang negatif atau kurang menguntungkan bagi pertumbuhan dan produksi tanaman yang ditanam pada tanahtanah sawah di lahan suboptimal. Sifat kimia tanah sawah lebih merupakan penyebab lahan sawah suboptimal serta rendahnya produktivitas lahan sawah suboptimal. .

\section{Kesimpulan}

Secara keseluruhan kualitas sifat fisik lahan sawah marjinal pada lokasi penelitian di Provinsi Banten dan Jawa Barat tergolong baik, bervariasi dari 4,30 sampai 4,70 dengan rata-rata 4,45. Kualitas sifat kimia secara keseluruhan tergolong sedang, namun terdapat perbedaan variasi penyebaran kualitas sifat kimia tanah antara lahan sawah marjinal di Provinsi Banten dan Jawa Barat. Penyebaran kualitas sifat kimia tanah lahan sawah di Provinsi Banten bervariasi dari 2,46 (katagori buruk) sampai 3,64 (katagori agak tinggi) dengan rata-rata 3,09 (katagori sedang). Kualitas sifat kimia lahan sawah di Provinsi Jawa Barat bervariasi dari 3,03 (katagori sedang) sampai 3,68 (katagori agak baik) dengan rata-rata 3,33 (katagori sedang). Sifat-sifat fisik tanah bukan penyebab rendahnya kualitas tanah dan produktivitas tanah pada lahan marjinal atau suboptimal. Penyebab utama rendahnya kualitas tanah dan produktivitas tanah lahan sawah pada lahan marjinal adalah sifat-sifat kimianya. Faktor pembatas yang paling banyak terdapat di tanah sawah pada lahan marjinal adalah sangat rendahnya fosfor tersedia dan karbon organik tanah untuk unsur makro serta terlampau tingginya kandungan feri dan mangan untuk unsur mikro. 
Jurnal Tanah dan Sumberdaya Lahan Vol 7 No 2 : 225-236, 2020

e-ISSN:2549-9793, doi: 10.21776/ub.jts1.2020.007.2.6

Tabel 5. Sifat-sifat kimia tanah dan masing-masing skornya serta skor akhirnya.

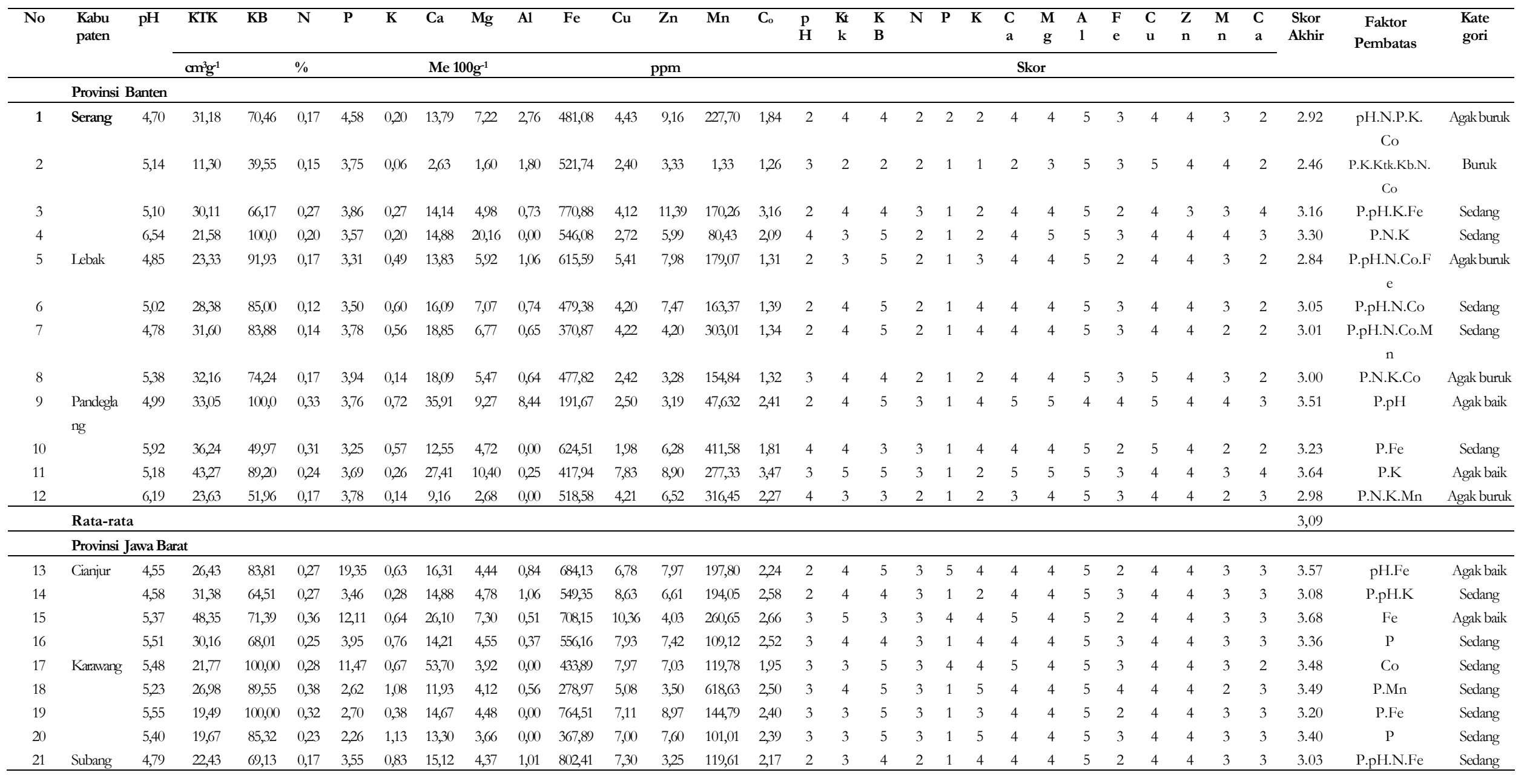


Jurnal Tanah dan Sumberdaya Lahan Vol 7 No 2 : 225-236, 2020

e-ISSN:2549-9793, doi: 10.21776/ub.jts1.2020.007.2.6

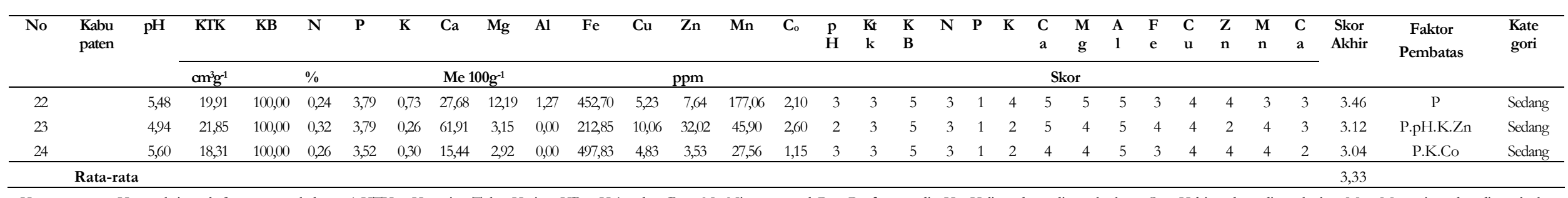

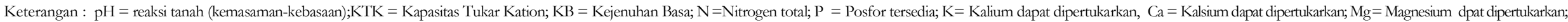
$\mathrm{Al}=\mathrm{Kejenuhan}$ Alumunium; $\mathrm{Fe}=\mathrm{Feri} ; \mathrm{Cu}=\mathrm{Cuprum} ; \mathrm{Zn}=\mathrm{Zink} ; \mathrm{Mn}=$ Mangan; $\mathrm{C}_{0}=$ Karbon organik 


\section{Jurnal Tanah dan Sumberdaya Lahan Vol 7 No 2 : 225-236, 2020 e-ISSN:2549-9793, doi: 10.21776/ub.jts1.2020.007.2.6}

Meskipun hanya didukung jumlah data yang relatif sedikit, namun data diambil dari lokasi penelitian tanah-tanah sawah yang merupakan sentra tanaman padi di Pulau Jawa, khususnya di Provinsi Jawa Barat dan Banten sehingga dapat dijadikan acuan awal untuk mengungkap karakteristik tanah yang menyebabkan rendahnya produktivitas tanah pada lahan-lahan marjinal atau suboptimal yang tersebar di seluruh Indonesia.

\section{Ucapan Terima Kasih}

Penulis mengucapkan terima kasih kepada Kementerian Riset, Teknologi, dan Pendidikan Tinggi Republik Indonesia atas dukungan pendanaan melalui skema Penelitian Terapan Unggulan Perguruan Tinggi.

\section{Daftar Pustaka}

Aprisal, Rusman, B., Dwipa, I., Rahmayuni, E., dan Fajriwandi. 2016. Dinamika beberapa sifat fisika tanah dibawah sistem usahatani konservasi pada lahan kritis aripan di DTA Singkara. Journal of Suboptimal Land 5(2): 175-182.

Arya, L.M., Bowman, D.C., Thapa, B.B. and Cassel, D. K. 2008. Scaling soil water characteristics of golf course and athletic field sands from particlesize distribution. Soil Science Society of America Journal 72(1): 25-32. https://doi.org/10.2136/sssaj2006.0232.

Beringer, H. 1980. The Role of Potassium in Crop Production. Proceedings of International Seminar on The Role of Potassium in Crop Production, 25-32. FSSA.

de Paul Obade, V. and Lal, R. 2014. Soil quality evaluation under different land management practices. Environmental Earth Sciences 72: 4531-4549. https://doi.org/10.1007/s12665014-3353-z.

Doran, J.W. and Parkin, T.B. 1994. Defining and Assessing Soil Quality. In J. W. Doran, D. C. Coleman, D. F. Bezdicek, dan B. A. Stewart (Eds.), Defiining Soil Quality for A Sustainable Environment (pp. 1-21). https://doi.org/10.2136/sssaspecpub35.frontm atter.

Elhakim, A.F. 2016. Estimation of soil permeability. Alexandria Engineering Journal, 55(3), 26312638. https://doi.org/10.1016/j.aej.2016.07.034

Faozi, K. dan Wijonarko, B.R. 2010. Serapan nitrogen dan beberapa sifat fisiologi tanaman padi sawah dari berbagai umur pemindahan bibit. Pembangunan Pedesaan 10(2): 93-101.
Fu, Y., Tian, Z., Amoozegar, A. and Heitman, J. 2019. Measuring dynamic changes of soil porosity during compaction. Soil and Tillage Research 193: 114-121. https://doi.org/10.1016/j.still.2019.05.016.

Hesse, P. R. 1984. Potential of Organic Materials for Soil Improvement. In Organic Matter and Rice (pp. 35-44). Losbanos (Filiphines): International Rice Research Institute (IRRI).

Holthusen, D., Brandt, A.A., Reichert, J.M. and Horn, R. 2018. Soil porosity, permeability and static and dynamic strength parameters under native forest/grassland compared to no-tillage cropping. Soil and Tillage Research 177: 113124. https://doi.org/10.1016/j.still.2017.12.003.

Hornick, S.B. 1992. Factors affecting the nutritional quality of crops. American Journal of Alternative Agriculture 7(1-2): 63-68. https://doi.org/10.1017/S0889189300004471.

Hosseini, F., Mosaddeghi, M.R., Hajabbasi, M.A., and Sabzalian, M.R. 2016. Role of fungal endophyte of tall fescue (Epichloë coenophiala) on water availability, wilting point and integral energy in texturally-different soils. Agricultural Water Management 163: 197-211. https://doi.org/10.1016/j.agwat.2015.09.024.

Kiani, M., Hernandez-Ramirez, G., Quideau, S., Smith, E., Janzen, H., Larney, F. J. and Puurveen, D. 2017. Quantifying sensitive soil quality indicators across contrasting long-term land management systems: Crop rotations and nutrient regimes. Agriculture, Ecosystems and Environment 248: 123-135. https://doi.org/10.1016/j.agee.2017.07.018.

Lal, R. 2001. Mananging world soils for food security and environmental quality. Advances in Agronomy 74: 502-515. https:/ /doi.org/10.1016/S0065-2113(01)740333.

Las, I. dan Mulyani, A. 2009. Strategi Penanganan Krisis Sumberdaya Lahan untukMendukung Kedaulatan Pangan dan Energi. Dalam S.D. Tarigan, B. Barus, D.R. Panuju, B.H. Trisasogko, dan B. Nugroho (Eds.), Prosiding Semiloka: Strategi Penanganan Krisis Sumberdaya Lahan Untuk Mendukung Kedaulatan Pangan dan Energi (pp. 13-14). Bogor: Departemen Ilmu Tanah dan Sumberdaya Lahan (IPB).

Lawes, R.A., Oliver, Y.M. and Robertson, M. J. 2009. Integrating the effects of climate and plant available soil water holding capacity on wheat yield. Field Crops Research 113(3): 297-305. https://doi.org/10.1016/j.fcr.2009.06.008.

Lu, Y., Si, B., Li, H., dan Biswas, A. 2019. Elucidating controls of the variability of deep soil bulk density. Geoderma 348: 146-157. https://doi.org/10.1016/j.geoderma.2019.04.03 
Jurnal Tanah dan Sumberdaya Lahan Vol 7 No 2 : 225-236, 2020

e-ISSN:2549-9793, doi: 10.21776/ub.jts1.2020.007.2.6

3.

Martín, M.Á., Reyes, M. dan Taguas, F.J. 2017. Estimating soil bulk density with information metrics of soil texture. Geoderma 287: 66-70. https://doi.org/10.1016/j.geoderma.2016.09.00 8.

Mengel, K. and Kirkby, E.A. 1978. Principle of Plant Nutrition. Worblaufen-Beru, Switzerland: International Potash Institute.

Mulyani, A., Agus, F. dan Las, I. 2018. Rekomendasi Kebijakan Dalam Upaya Percepatan Implementasi Undang-Undang N0.41/2019 Dalam Megendalikan Konversi Lahan Sawah. Dalam Sukarman, F. Agus, dan I. Las (Eds.), Kumpulan Policy Brief: Kebijakan Sumberdaya Lahan Mendukung Pembangunan Pertanian (pp. 21-30). Bogor: Balai Besar Penelitian dan Pengembangan Sumberdaya Lahan Pertanian (BBSDLP).

Rachman, L.M. 2019. Karakteristik dan Variabilitas Sifat-Sifat Fisik Tanah dan Evaluasi Kualitas Fisik Tanah pada Lahan Suboptimal. In S. Herlinda, B. Lakitan, W. Budiharto, I. Effendi, D. Adriani, M. Wijayanti, ... Tanbiyaskur (Eds.), Prosiding Seminar Nasional Lahan Suboptimal 2019, Palembang 4 - 5 September 2019 (pp. 132 139). Palembang: UNSRI Press.

Regelink, I.C., Stoof, C.R., Rousseva, S., Weng, L., Lair, G.J., Kram, P. and Comans, R.N.J. 2015. Linkages between aggregate formation, porosity and soil chemical properties. Geoderma 247248: 24-37. https://doi.org/10.1016/ j.geoderma.2015.01.022.
Rojas, J.M., Prause, J., Agustín, G., Ernesto, O., Arce, A. and Cristina, M. 2016. Soil quality indicators selection by mixed models and multivariate techniques in deforested areas for agricultural use in NW of Chaco, Argentina. Soil \& Tillage Research 155: 250-262. https://doi.org/ 10.1016/j.still.2015.08.010

Subandi. 2013. Peran dan pengelolaan hara kalium untuk produksi pangan di Indonesia. Jurnal Pengembangan Inovasi Pertanian 6(1): 1-10.

Suyono, A.D. dan Citraresmini, A. 2010. Komposisi kandungan fosfor pada tanaman padi sawah (Oryza sativa L.) berasal dari pupuk P dan bahan organik. Bionatura 12(3): 126-135.

Umar, S. 2018. Swasembada Pangan: Revitalisasi Jaringan Irigasi. Dalam Sukarman, F. Agus, dan I. Las (Eds.), Kumpulan Policy Brief: Kebijakan Sumberdaya Lahan Mendukung Pembangunan Pertanian (pp. 137-144). Bogor: Balai Besar Penelitian dan Pengembangan Sumberdaya Lahan Pertanian (BBSDLP).

Zuber, S.M., Behnke, G.D., Nafziger, E.D. and Villamil, M.B. 2017. Multivariate assessment of soil quality indicators for crop rotation and tillage in Illinois. Soil and Tillage Research 174: $147-$ 155. https://doi.org/10.1016/j.still.2017.07.007. 